Jurnal Ekonomi dan Industri

e-ISSN: $2656-3169$

Volume 22, No.3, September-Desember 2021

p- ISSN: 0853-5248

\title{
TINGKAT LITERASI KEUANGAN MAHASISWA UNIVERSITAS DARMA PERSADA DAN FAKTOR-FAKTOR YANG MEMPENGARUHINYA
}

\author{
Hasri Nirmala Budiarti ${ }^{1)}$ dan Puji Rahayu Setyaningsih ${ }^{2)}$ \\ Jurusan Akuntansi FE Unsada \\ 1) hasri_nirmala@fe.unsada.ac.id \\ Alumnus Magister Akuntansi Program Akuntansi Keuangan \\ Universitas Mercu Buana \\ 2)rpuji.rahayus76@gmail.com
}

\begin{abstract}
The purpose of this research is to find out the level of financial literacy of students at Darma Persada University. This research is a quantitative descriptive study that uses a population of all students of the Faculty of Economics at Darma Persada University Jakarta. The sampling technique was carried out by purposive sampling. Data were collected through questionnaires distributed and analyzed using descriptive statistics and multiple regression analysis. The financial literacy of Darma Persada University students is in the good category. The results showed that age, sex and education, partially had no effect on the financial literacy. While the income variable affects the financial literacy variable Simultaneously, the age, gender, education and income variables affect the financial literacy variable.
\end{abstract}

Keywords: Financial literacy, socio demographic, college students

\section{PENDAHULUAN}

Beberapa tahun terakhir topik literasi (pengetahuan) keuangan telah menjadi salah satu fokus kebijakan pemerintah di berbagai negara tak terkecuali di Indonesia. Pembangunan ekonomi yang sedang berlangsung saat ini tidak semata-mata bertujuan untuk meningkatkan kesejahteraan masyarakat secara keseluruhan namun juga mempunyai tujuan untuk menciptakan manusia Indonesia yang berwawasan luas dan memiliki pandangan jauh ke depan. Untuk itu, pembangunan ekonomi tidak hanya dilakukan melalui pembangunan sarana fisik yang dapat dilihat dan dirasakan langsung oleh masyarakat, tetapi juga melalui pengembangan kemampuan berpikir manusia Indonesia. Salah satunya adalah mengembangkan kemampuan berpikir masyarakat Indonesia dalam hal pengelolaan keuangan. Faktanya masih ada masyarakat yang malas ataupun masih ragu untuk memanfaatkan lembaga keuangan, selain itu ada juga yang belum mengakses produk/layanan keuangan karena memang tidak tahu cara, fungsi dan manfaatnya hingga masih banyak masyarakat Indonesia yang pengetahuan tentang sektor keuangannya rendah. Lembaga Otoritas Jasa Keuangan (OJK) telah berupaya untuk meningkatkan pemahaman masyarakat dan konsumen mengenai Lembaga Jasa Keuangan (LJK) serta produk dan jasa yang ditawarkan di industri keuangan. Dengan demikian tingkat pengetahuan mengenai industri keuangan akan meningkat dan pada akhirnya akan meningkatkan tingkat utilitas dan kepercayaan masyarakat serta konsumen terhadap lembaga dan produk jasa keuangan di Indonesia (financial well-literate). Literasi keuangan terjadi manakala seorang individu memiliki sekumpulan keahlian dan kemampuan yang membuat orang tersebut mampu memanfaatkan sumber daya yang ada untuk mencapai tujuan. Individu yang memiliki kemampuan untuk membuat keputusan yang benar tentang keuangan tidak akan memiliki 
masalah keuangan di masa depan dan dapat menunjukkan perilaku keuangan yang sehat serta mampu menentukan prioritas kebutuhan bukan keinginan.

Menyadari pentingnya literasi keuangan bagi masyarakat ini, pemerintah gencar melakukan berbagai upaya yang ditujukan untuk menaikkan tingkat pemahaman masyarakat akan sektor keuangan dan akses ke sektor keuangan (dari yang sama sekali tidak punya akses hingga menjadi nasabah atau konsumen di sektor keuangan atau istilah yang lebih sering didengar, dari unbankable menjadi bankable). Paling penting lagi, upaya ini juga dimaksudkan untuk menghindari masyarakat dari investasi bodong (ilegal) yang saat ini cukup ramai di Indonesia.

Berdasarkan hasil Survei Nasional Literasi dan Inklusi Keuangan (SNLIK) yang dilakukan Otoritas Jasa Keuangan (OJK) pada tahun 2019 kemarin, tingkat literasi keuangan dan inklusi keuangan 2019 masing-masing mencapai 38,03\% dan 76,19\%. Angka ini cukup menggembirakan karena Indonesia telah berhasil melampaui target yang ditetapkan oleh pemerintah dalam Peraturan Presiden No. 82 tahun 2016 tentang Strategi Nasional Keuangan Inklusif (SNKI) sebesar 75\% untuk tingkat inklusi keuangan, sementara target tingkat literasi keuangan yang ditetapkan dalam Peraturan Presiden No. 50 tahun 2017 tentang Strategi Nasional Perlindungan Konsumen sebesar 35\% juga telah terlampaui. Angka ini menunjukkan peningkatan cukup signifikan dari survei sebelumnya di tahun 2016 dimana terdapat peningkatan pemahaman keuangan (awareness) masyarakat sebesar $8,33 \%$ serta peningkatan akses terhadap produk dan layanan jasa keuangan sebesar $8,39 \%$.

Pemahaman keuangan (literasi) masyarakat sebesar 10,83 persen, serta peningkatan akses terhadap produk dan layanan jasa keuangan (inklusi keuangan) sebesar 14,44 persen. Kesenjangan atau celah antara indeks literasi keuangan dan indeks inklusi keuangan tersebut menjadi celah terjadinya berbagai macam permasalahan di sektor jasa keuangan. Masyarakat yang memiliki akses keuangan belum sepenuhnya memahami karakterisitk dan resiko produk jasa keuangan yang dimiliki. Apalagi dalam situasi pandemic COVID 19 tekanan terhadap kebutuhan biaya hidup yang meningkat sementara disisi lain ada pembatasan dalam melakukan kegiatan usaha. Hal itu akan menjadi celah maraknya penawaran investasu dengan keuntungan yang tinggi dalam waktu singkat atau penawaran pinjaman online illegal. Untuk itulah maka OJK terus berupaya meningkatkan pemahaman masyaraakat dengan melibatkan berbagai pihak termasuk dari mahasiswa.

Peran mahasiswa sangat penting dalam fungsi literasi dan edukasi keuangan, mengingat eksistensi dan kedekatan mahasiswa dengan masyarakat. Peran aktif mahasiswa sebagai agen perubahan diharapkan dapat membantu pemerintah dalam meningkatkan inklusi serta literasi keuangan yang saat ini dinilai masih kurang. Mahasiswa termasuk dalam sekelompok warga negara yang berpendidikan yang memberi kontribusi dan memiliki peran untuk memajukan perekonomi negara (Sirine dan Utami, 2016). Mahasiswa selama masa kuliahnya mengalami perubahan dalam hal keuangan dari masih memiliki ketergantungan dari orang tua menjadi mandiri. Pada masa ini, mahasiswa dituntut untuk bertanggung jawab pada pilihan keuangannya. Mahasiswa cenderung masih sulit untuk mengatur keuangan yang didapat dari uang saku dari orang tua, sehingga seringkali mahasiswa tidak memiliki dana simpanan. Jika ada keperluan mendadak di masa mendatang akan mengalami kesulitan dalam hal keuangannya. Oleh karena itu mahasiswa harus mulai belajar untuk mengatur keuangannya. Pengetahuan tentang pengelolaan keuangan penting untuk bekal mahasiswa untuk mulai belajar mandiri. Mahasiswa perguruan tinggi negeri prodi akuntansi baik murni ataupun pendidikan tentunya lebih memahami tentang pengelolaan keuangan, menabung dan investasi karena materi pembelajaran tersebut sudah dipelajari di perkuliahan. 
Pemahaman mahasiswa akuntansi terhadap pengelolaan keuangan cenderung akan mempengaruhi mahasiswa dalam menentukan keputusan dalam hal menabung.

Pembelajaran mengenai literasi keuangan tidak diberikan dalam mata kuliah tersendiri, namun aspek-aspek literasi keuangan dapat ditemui dalam beberapa mata kuliah keuangan antara lain, mata kuliah manajemen keuangan, bank dan lembaga keuangan lainnya, investasi dan pasar modal, serta akuntansi keuangan. Mata kuliah tersebut diberikan pada mahasiswa Fakultas Ekonomi. Hal ini tidak berlaku pada mahasiswa yang berasal dari fakultas non-Ekonomi. Mahasiswa dari fakultas non-ekonomi hanya memperoleh pengetahuan keuangan melalui mata kuliah Kewirausahaan. Ditambah lagi, apabila dalam mata kuliah kewirausahaan dosen kurang memfokuskan penyampaian materi pada aspek keuangan. Hal ini yang menyebabkan tingkat literasi keuangan pada mahasiswa masih rendah.

Pentingnya meningkatkan pemahaman akan literasi keuangan di kalangan mahasiswa, sudah merupakan suatu hal yang perlu mendapatkan perhatian serius dari para stakekolder. Pembelajaran di perguruan tinggi bertujuan mencetak lulusan yang memiliki prestasi akademik yang sesuai dengan jurusan dan mampu menjadi insan yang mandiri dan bertanggung jawab terhadap semua pilihan dan resiko yang diambilnya. Termasuk dalam pengelolaan keuangan yang diperoleh dari orang tua maupun sumber lain seperti beasiswa atau bisnis yang digeluti. Mahasiswa sering dihadapkan pada berbagai pilihan keuangan yang cukup rumit, mulai dari membayar uang kuliah, sewa kos, membuat anggaran, menabung, mengikuti asuransi, dan bahkan ada yang bekerja, sehingga mahasiswa harus menyeimbangkan kehidupannya baik di tempat kerja, kuliah, dan kehidupan sosial mereka. Berdasarkan hal tersebut, pembelajaran di perguruan tinggi sangat berperan penting dalam proses pembentukan literasi keuangan mahasiswa yang berdampak pada perilaku keuangan mahasiswa. Dengan literasi keuangan yang baik diharapkan mahasiswa memiliki kecakapan di bidang keuangan, sehingga mampu menjadi mahasiswa yang siap menata kehidupan masa kini dan masa depan dengan lebih baik.

Morgana dan Quang (2020) menunjukkan bahwa individu dengan skor literasi keuangan yang lebih tinggi lebih mungkin untuk menyimpan tabungan baik dalam bentuk formal maupun informal mahasisway ang memiliki skor literasi keuangan yang lebih rendah, bahkan ketika mengontrol pendapatan dan pendidikan. Lalu penelitian Lyons dan Hanna (2019) menemukan bahwa penduduk yang secara ekonomi belum mapan juga dapat dikatakan belum mapan secara finansial. Masyarakat yang tinggal di negara-negara MENA dengan tingkat literasi keuangan yang lebih tinggi lebih cenderung memiliki perilaku menabung yang positif dan cenderung tidak memiliki pinjaman, terutama dari sumber pinjaman informal. Literasi keuangan dan karakteristik makro lainnya, tidak berhubungan langsung, terutama bagi mereka yang paling rentan.

Hal ini bertentangan dengan hasil penelitian dari Kabakova dan Plaksenkov (2018) yang dalam penelitiannya menemukan bahwa ada tiga konfigurasi faktor yang mempengaruhi inklusi keuangan: faktor sosial-demografis dan politik yang tinggi tanpa adanya pembangunan ekonomi; faktor sosial, teknologi dan ekonomi yang tinggi tanpa adanya pembangunan politik; dan faktor politik dan ekonomi tanpa adanya perkembangan sosial dan teknologi. Dua kombinasi faktor yang mempengaruhi eksklusi keuangan adalah tidak adanya faktor sosial dan ekonomi pada perkembangan politik dan teknologi; dan terakhir konfigurasi tanpa faktor sosial-demografis, teknologi dan politik pembangunan. Penelitian Adetunji dan West (2019) mengatakan literasi keuangan secara signifikan menentukan pola tabungan baik melalui lembaga keuangan formal maupun informal; namun, pendapatan hanya mendorong frekuensi tabungan informal. Hasilnya juga 
menyoroti kelompok demografis yang cocok untuk literasi keuangan dan intervensi lain yang bertujuan untuk meningkatkan akses keuangan.

Dari penelitian-penelitian tersebut diperoleh beberapa faktor yang mempengaruhi literasi keuangan individu antara lain: personal demografi, karakteristik sosial dan ekonomi, pengalaman dalam hal pengelolaan keuangan, pendidikan keuangan, pendapatan, status sosial, serta letak geografis. Karakteristik sosial demografi merupakan ciri yang menggambarkan perbedaan masyarakat berdasarkan usia, jenis kelamin, pekerjaan, pendidikan, agama, suku, ras, jenis keluarga, status perkawinan, jumlah pendapatan, status sosial. Karakteristik sosial demografi merupakan bagian yang melekat pada individu dan mampu mempengaruhi individu untuk pengambilan keputusan. Dalam penelitian ini karakteristik sosial demografi yang akan dijadikan fokus penelitian dilihat dari: gender, usia, pendidikan, pengetahuan mengenai keuangan dan pengalaman keuangan.

Berdasarkan latar belakang tujuan penelitian ini antara lain: 1) Menganalisa tingkat literasi keuangan mahasiswa fakutltas ekonomi Universitas Darma Persada. 2) Menganalisis pengaruh usia terhadap literasi keuangan pada mahasiswa fakultas ekonomi Universitas Darma Persada. 3) Menganalisis pengaruh Jenis Kelamin terhadap literasi keuangan pada mahasiswa fakultas ekonomi Universitas Darma Persada. 4) Menganalisis pengaruh pendidikan terhadap pada mahasiswa fakultas ekonomi Universitas Darma Persada. 5) Menganalisis pengaruh penghasilan terhadap pada mahasiswa fakultas ekonomi Universitas Darma Persada.

\section{LANDASAN TEORI}

\section{Literasi Keuangan}

Literasi keuangan adalah pengetahuan seseorang berkaitan keuangan dan kemampuannya dalam menerapkan pengetahuan dalam bentuk pengelolaan keuangan pribadi meliputi manajemen hutang, tabungan, serta perencanaan keuangan masa depan (Huston, 2010). Manfaat literasi keuangan adalah agar seseorang bisa mengelola uang dan mengambil peluang untuk meraih kehidupan yang lebih sejahtera di masa yang akan datang. Literasi keuangan juga sangat membantu seseorang untuk membuat keputusan utamanya yang berhubungan dengan pengambilan keputusan untuk menabung atau investasi. Faktorfaktor yang mempengaruhi literasi keuangan terdiri atas usia, jenis kelamin, pendidikan dan penghasilan.

\section{METODE PENELITIAN}

Penelitian ini merupakan penelitian deskriptif kuantitatif yang menggunakan populasi seluruh mahasiswa Fakultas Ekonomi Universitas Darma Persada Jakarta Teknik. Pengambilan sampel dilakukan dengan cara purposif sampling dengan jumlah sampel sebanyak 256 responden. Data yang dikumpulkan dalam penelitian ini bersumber dari jawaban kuesioner yang diberikan kepada mahasiswa S1 Fakultas Ekonomi Univesitas Dharma Persada. Data dianalisis menggunakan analisis regresi berganda. 


\section{HASIL PENELITIAN DAN PEMBAHASAN}

\section{Hasil Penelitian}

\section{Analisis Deskriptif}

Hasil penelitian menunjukkan gambaran umum responden yang dilihat dari sosio demografi dalam tabel berikut:

Tabel 1: Identitas Responden

\begin{tabular}{lcc}
\hline \multicolumn{1}{c}{ Uraian } & Frekuensi & Prosentase \\
\hline Jenis Kelamin & & \\
Laki-Laki & 37 & $14,5 \%$ \\
Perempuan & 219 & $85,5 \%$ \\
\hline Usia & 71 & $27,7 \%$ \\
$<20$ tahun & 176 & $68,8 \%$ \\
21 - 30 tahun & 8 & $3,1 \%$ \\
$31-40$ tahun & 1 & $0,4 \%$ \\
$41-50$ tahun & 0 & $0 \%$ \\
$>50$ tahun & & \\
\hline Pendidikan & 117 & $45,7 \%$ \\
SMA/MA & 1 & $0,4 \%$ \\
Diploma & 136 & $53,1 \%$ \\
S1 & 2 & $0,8 \%$ \\
S2/S3 & & \\
Penghasilan & 156 & $60,9 \%$ \\
$<$ Rp 500.000 & 44 & $17,2 \%$ \\
Rp 500.000 - Rp 2.000.000 & 45 & $17,6 \%$ \\
Rp 2.000.000 - Rp 5.000.000 & 7 & $2,7 \%$ \\
Rp 5.000.000 - Rp 7.000.000 & 4 & $1,6 \%$ \\
$>$ Rp 7.000.000 &
\end{tabular}

Sumber: Data yang diolah dengan SPSS ver 26

Berdasarkan tabel 1 dapat dilihat gambaran responden tentang jenis kelamin, umur dan masa kerja. Berdasarkan dari jenis kelamin, responden perempuan lebih banyak yaitu 219 orang $(85,5 \%)$. Berdasarkan usia, responden paling banyak berusia 21-30 tahun yaitu sebanyak 176 orang $(68,8 \%)$, sedangkan berdasarkan pendidikan, responden yang memiliki latar belakang S1 adalah terbanyak sebesar $136(53,1 \%)$. Penghasilan orang tua terbanyak pada kisaran kurang dari Rp 500.000 sebanyak 156 orang (60,9\%).

Ukuran deskriptif adalah pemberian angka, baik dalam jumlah responden beserta nilai rata-rata jawaban responden maupun dalam bentuk prosentase (Wati, 2018:118). Untuk mencari nilai interval digunakan rumus sebagai berikut:

$$
I=\frac{\text { Skor Max-Skor Min }}{\text { Kelas }}
$$


Keterangan:

I $\quad=$ interval

Skor Max = Skor maksimal dari jawaban responden (5)

Skor min $=$ Skor minimal dari jawaban responden (1)

Kelas $=$ kelas / jumlah obyek pilihan

Berdasarkan rumus tersebut maka nilai intervalnya sebagai berikut:

$$
I=\frac{5-1}{5}=0,8
$$

Berdasarkan nilai interval diatas, maka rentang nilai untuk jawaban responden terhadap kuesioner penelitian dapat dilihat pada tabel berikut ini:

Tabel 2: Tabel Rentang Nilai

\begin{tabular}{ccc}
\hline No & Rentang Nilai & Kategori \\
\hline 1 & $1,00-1,80$ & Tidak Baik \\
2 & $1,81-2,60$ & Kurang Baik \\
3 & $2,61-3,40$ & Cukup Baik \\
4 & $3,41-4,20$ & Baik \\
5 & $4,21-5,00$ & Sangat Baik \\
\hline
\end{tabular}

Variabel literasi keuangan memiliki 19 item pertanyaan pada kuesioner. Tabel berikut berisikan rangkuman skor rata-rata jawaban responden atas pertanyaan tentang literasi keuangan.

Tabel 3. Rekapitulasi Skor Responden Terhadap Variabel Literasi Keuangan

\begin{tabular}{|c|c|c|c|c|c|c|c|c|c|}
\hline No & Butir Pertanyaan & $\begin{array}{c}\text { SS } \\
5\end{array}$ & $\mathbf{S}$ & $\begin{array}{l}\mathbf{R} \\
\mathbf{3}\end{array}$ & $\begin{array}{c}\text { TS } \\
2\end{array}$ & STS & TOTAL & $\begin{array}{l}\text { Total } \\
\text { Skor }\end{array}$ & $\begin{array}{l}\text { Rata- } \\
\text { rata } \\
\text { Slar }\end{array}$ \\
\hline 1 & $\begin{array}{l}\text { Saya memiliki pengetahuan akuntansi } \\
\text { dasar }\end{array}$ & 57 & 184 & 15 & & & 256 & 1066 & 4,16 \\
\hline 2 & $\begin{array}{l}\text { Saya memahami manfaat pengelolaan } \\
\text { keuangan }\end{array}$ & 56 & 189 & 11 & & & 256 & 1069 & 4,18 \\
\hline 3 & $\begin{array}{l}\text { Saya memahami cara mengelola } \\
\text { keuangan secara efektif }\end{array}$ & 39 & 165 & 51 & 1 & & 256 & 1010 & 3,95 \\
\hline 4 & $\begin{array}{l}\text { Saya mengetahui syarat yang } \\
\text { diperlukan untuk mendapatkan } \\
\text { pinjaman dari bank }\end{array}$ & 108 & 21 & 100 & 25 & 2 & 256 & 976 & 3,81 \\
\hline 5 & $\begin{array}{l}\text { Saya mengetahui manfaat dan fasilitas } \\
\text { yang ditawarkan oleh bank }\end{array}$ & 18 & 133 & 91 & 14 & & 256 & 923 & 3,61 \\
\hline 6 & Saya memahami konsep bunga & 75 & 161 & 14 & 6 & & 256 & 1073 & 4,19 \\
\hline 7 & $\begin{array}{l}\text { Saya berhati-hati dalam mengambil } \\
\text { kredit atau hutang }\end{array}$ & 149 & 102 & 2 & 3 & & 256 & 1165 & 4,55 \\
\hline 8 & $\begin{array}{l}\text { Saya dapat menganalisis kinerja } \\
\text { keuangan secara berkala }\end{array}$ & 136 & 93 & 19 & 8 & & 256 & 1125 & 4,39 \\
\hline 9 & $\begin{array}{l}\text { Saya bisa membuat pembukuan kas } \\
\text { keluar-masuk perhari }\end{array}$ & 46 & 169 & 33 & 8 & & 256 & 1021 & 3,99 \\
\hline 10 & $\begin{array}{l}\text { saya mengerti perbedaan investasi dan } \\
\text { menabung. }\end{array}$ & 70 & 168 & 18 & & & 256 & 1076 & 4,20 \\
\hline 11 & $\begin{array}{l}\text { Saya mengetahui pasar modal } \\
\text { merupakan salah satu alat investasi }\end{array}$ & 46 & 170 & 38 & 2 & & 256 & 1028 & 4,02 \\
\hline 12 & $\begin{array}{l}\text { Saya memahami berbagai jenis } \\
\text { investasi }\end{array}$ & 23 & 136 & 84 & 13 & & 256 & 937 & 3,66 \\
\hline
\end{tabular}




\begin{tabular}{|c|c|c|c|c|c|c|c|c|c|}
\hline \multirow{2}{*}{ No } & \multirow{2}{*}{ Butir Pertanyaan } & SS & $\mathbf{S}$ & $\mathbf{R}$ & TS & STS & \multirow{2}{*}{ TOTAL } & \multirow{2}{*}{$\begin{array}{l}\text { Total } \\
\text { Skor }\end{array}$} & \multirow{2}{*}{$\begin{array}{c}\text { Rata- } \\
\text { rata } \\
\text { Skor }\end{array}$} \\
\hline & & 5 & 4 & 3 & 2 & 1 & & & \\
\hline 13 & $\begin{array}{l}\text { Saya mengetahui perbedaan reksadana } \\
\text { dan saham }\end{array}$ & 31 & 115 & 93 & 17 & & 256 & 928 & 3,63 \\
\hline 14 & $\begin{array}{l}\text { Saya mengetahui setiap kegiatan } \\
\text { investasi terdapat resiko investasi }\end{array}$ & 61 & 150 & 40 & 5 & & 256 & 1035 & 4,04 \\
\hline 15 & $\begin{array}{l}\text { Saya dapat mengatur strategi untuk } \\
\text { meminimalkan resiko keuangan }\end{array}$ & 27 & 141 & 81 & 7 & & 256 & 956 & 3,73 \\
\hline 16 & $\begin{array}{l}\text { Saya memiliki pengetahuan umum } \\
\text { tentang asuransi }\end{array}$ & 18 & 147 & 75 & 16 & & 256 & 935 & 3,65 \\
\hline 17 & $\begin{array}{l}\text { Saya memahami berbagai jenis } \\
\text { asuransi }\end{array}$ & 18 & 104 & 115 & 19 & & 256 & 889 & 3,47 \\
\hline .18 & $\begin{array}{l}\text { Saya mengetahui adanya resiko } \\
\text { asuransi }\end{array}$ & 22 & 160 & 60 & 12 & 2 & 256 & 956 & 3,73 \\
\hline 19 & $\begin{array}{l}\text { saya memahami cara terbentuknya } \\
\text { suatu harga jual }\end{array}$ & 24 & 151 & 77 & 4 & & 256 & 963 & 3,76 \\
\hline
\end{tabular}

Sumber: Data yang diolah dengan SPSS ver 26

Berdasarkan tabel rekapitulasi skor responden terhadap pernyataan variabel literasi keuangan dengan jumlah responden 256 orang, diperoleh rata-rata total skor 3,93. Berdasarkan tabel rentang nilai, dapat disimpulkan bahwa variabel literasi keuangan termasuk dalam kategori baik.

\section{Hasil uji regresi linier berganda}

Analisis regresi selain digunakan untuk mengukur kekutan hubungan antara dua variabel atau lebih, juga menunjukan arah hubungan antara variabel dependen dan variabel independen (Sugiyono, 2018). Dalam penelitian ini, yaitu untuk menguji pengaruh Usia, Jenis Kelamin, Pendidikan dan Penghasilan terhadap Literasi Keuangan. Berikut ini adalah hasil uji regresi linear berganda dalam penelitian ini:

Tabel 4: Hasil Analisis Regresi Linear Berganda

\begin{tabular}{lcccccc}
\hline \multirow{2}{*}{ Variabel } & \multicolumn{6}{c}{ Parameter } \\
\cline { 2 - 7 } & $\begin{array}{c}\text { Mult. } \\
\text { R }\end{array}$ & $\begin{array}{c}\mathbf{R} \\
\text { Square }\end{array}$ & Konstanta & $\begin{array}{c}\text { Koefisien } \\
\text { Regresi }\end{array}$ & Sig. & $\boldsymbol{\alpha}$ \\
\hline Usia & 0,832 & & & 1,038 & 0,293 \\
Jenis_Kelamin & & 0,077 & 70,233 & $-1,146$ & 0,379 & 0,05 \\
Pendidikan & & & & 0,058 & 0,900 & 0 \\
Penghasilan & & & 1,849 & 0,001 & \\
\hline Pengujian Signifikan & & & & & \\
\hline F hitung = 5,266 & & & & & \\
\hline Sumber: Data primer, diolah 2021
\end{tabular}

Nilai F hitung sebesar 5,266, artinya terdapat pengaruh secara bersama-sama usia, jenis kelamin, pendidikan dan penghasilan terhadap literasi keuangan. Nilai koefisien determinasi $\left(\mathrm{R}^{2}\right)$ adalah 0,077 . Hal ini menunjukkan bahwa kontribusi usia $\left(\mathrm{X}_{1}\right)$, jenis kelamin $\left(\mathrm{X}_{2}\right)$, pendidikan $\left(\mathrm{X}_{3}\right)$, dan penghasilan $\left(\mathrm{X}_{4}\right)$ kepada literasi keuangan $(\mathrm{Y})$ adalah sebesar 7,7\%, sedangkan sisanya sebesar $93,3 \%$ disumbangkan faktor lain.

Model regresi linier berganda dalam bentuk persamaan sebagai berikut: 


$$
Y=70,233+1,038 X_{1}-1,146 X_{2}+0,058 X_{3}+1,849 X_{4}
$$

Koefisien regresi Usia $\left(X_{1}\right)$ sebesar 1,038 mempunyai makna, apabila usia ditingkatkan sebesar 1 kali, maka literasi keuangan akan mengalami kenaikan, yaitu sebesar 1,038 kali dengan asumsi faktor lain yang mempengaruhinya dianggap konstan. Koefisien bernilai positif artinya terjadi hubungan searah antara usia dengan literasi keuagan. Semakin tinggi nilai usia, maka akan semakin tinggi literasi keuagan. Begitupun sebaliknya, semakin rendah nilai usia, maka akan semakin rendah nilai literasi keuangan.

Koefisien regresi jenis kelamin $\left(\mathrm{X}_{2}\right)$ sebesar minus 1,146 mempunyai makna, apabila jenis kelamin ditingkatkan sebesar 1 kali, maka literasi keuangan akan mengalami penurunan sebesar 1,146 kali dengan asumsi faktor lain yang mempengaruhinya dianggap konstan. Koefisien bernilai negatif artinya terjadi hubungan berlawanan arah antara jenis kelamin dengan literasi keuangan. Semakin tinggi nilai jenis kelamin, maka akan semakin rendah nilai literasi keuangan. Begitupun sebaliknya, semakin rendah nilai jenis kelamin, maka akan semakin tinggi nilai literasi keuangan.

Koefisien regresi pendidikan $\left(\mathrm{X}_{3}\right)$ sebesar 0,058 mempunyai makna, apabila pendidikan ditingkatkan sebesar 1 kali, maka nilai literasi keuangan akan mengalami kenaikan sebesar 0,058 kali dengan asumsi faktor lain yang mempengaruhinya dianggap konstan. Koefisien bernilai positif artinya terjadi hubungan searah antara pendidikan dengan literasi keuangan. Semakin tinggi nilai pendidikan, maka akan semakin tinggi nilai literasi keuangan. Begitupun sebaliknya, semakin rendah nilai pendidikan, maka akan semakin rendah nilai literasi keuangan.

Koefisien regresi penghasilan $\left(\mathrm{X}_{4}\right)$ sebesar 1,849 mempunyai makna, apabila penghasilam ditingkatkan sebesar $1 \mathrm{kali}$, maka nilai literasi keuangan akan mengalami kenaikan sebesar 1,849 kali dengan asumsi faktor lain yang mempengaruhinya dianggap konstan. Koefisien bernilai positif artinya terjadi hubungan searah antara penghasilan dengan literasi keuangan. Semakin tinggi nilai penghasilan, maka akan semakin tinggi nilai literasi keuangan. Begitupun sebaliknya, semakin rendah nilai penghasilan, maka akan semakin rendah nilai literasi keuangan.

\section{Pembahasan}

\section{Usia Berpengaruh terhadap Literasi Keuangan}

Usia tidak mendorong peningkatan literasi keuangan. Hasil penelitian ini sejalan dengan penelitian yang dilakukan oleh Laily (2013) yang menyatakan bahwa usia seseorang tidak berpengaruh terhadap literasi keuangan, Penelitian yang dilakukan Herawati (2017) menunjukkan bahwa usia berpengaruh negatif dan signifikan terhadap literasi keuangan mahasiswa. Hal ini disebabkan mahasiswa hanya memperoleh mata kuliah kewirausahaan di semester awal saja, sehingga pemahaman akan literasi keuangan mahasiswa di semester awal akan lebih baik dibandingkan dengan mahasiswa tingkat akhir. Yunita (2018) menyebutkan ketidaksignifikannya usia terhadap literasi keuangan karena dimungkinkan ada faktor lain yang mungkin mempengaruhinya seperti faktor lingkungan, kebiasaan pribadi, social budaya dan psikologis lainnya yang sulit diukur. Hasil ini berlawanan dengan penelitian yang dilakukan oleh Prayogi (2017) yang menyimpulkan bahwa usia mempengaruhi literasi keuangan dan bernilai negatif. Ini disebabkan penjelasan tentang pengetahuan keuangan dapat disampaikan dengan baik kepada anak dan orang tua.

\section{Jenis Kelamin Berpengaruh terhadap Literasi Keuangan}


Jenis kelamin tidak mendorong peningkatan literasi keuangan. Hasil penelitian ini sejalan dengan penelitian yang dilakukan oleh Laily (2013) menyebutkan bahwa gender tidak berpengaruh terhadap literasi keuangan, sedangkan dalam penelitian Prayogi (2017), jenis kelamin seseorang tidak menentukan kecerdasan dan kemampuan dalam mengelola keuangan pribadinya dikarenakan baik laki-laki maupun perempuan sama-sama memiliki rata-rata pendidikan tamatan SMA sehingga pemikiran mereka tidak jauh berbeda.

\section{Pendidikan Berpengaruh terhadap Literasi Keuangan}

Pendidikan tidak mendorong peningkatan literasi keuangan. Hasil penelitian ini sejalan dengan penelitian yang dilakukan oleh Yusnita (2018) yang menyebutkan pendidikan tidak berpengaruh terhadap literasi keuangan karena dari pelaku usaha sendiri banyak yang tidak mendapatkan ilmu keuangan saat sekolah, materi yang disekolah bersifat umum dan hanya sedikit menyinggung tentang ilmu keuangan, mereka hanya diajarkan sebagian kecil dari konsep-konsep dari imu keuangan seperti perhitungan bunga majemuk dan pemakaian produk perbankan. Mereka lebih diajarkan tentang bagaimana cara untuk berwirausaha dan bekerja namun tidak tentang bagaimana cara memanfaatkan pendapatan. Hasil dari penelitian ini berbeda dengan penelitian yang dilakukan oleh Prayogi (2017) yang menyebutkan bahwa semakin tinggi tingkat pendidikan individu maka akan semakin mahir dalam pengelolaan keuangannya.

\section{Penghasilan Berpengaruh terhadap Literasi Keuangan}

Penghasilan mendorong peningkatan literasi keuangan. Hasil penelitian ini sejalan dengan penelitian yang dilakukan oleh Prayogi (2017) menyebutkan bahwa semakin besar penghasilan maka semakin besar mengalokasikan pendapatannya kepada produk keuangan seperti tabungan, deposito dan lain-lain.Yunita (2018) yang menyatakan bahwa dengan tingginya tingkat penghasilan pelaku usaha akan mempengaruhi tingkat literasi keuangan mereka dan akan mendorong sebagian dari mereka menggunakan produk perbankan, asuransi dan lembaga kredit lainnya sehingga mereka bisa memiliki pengetahuan keuangan, kepandaian dan kecakapan pribadi dalam mengetahui konsep keuangan dan mengelola aset sebagai jaminan usahanya dimasa mendatang. Hasil penelitian ini tidak sejalan dengan penelitian yang dilakukan oleh Herawati (2017) yang menyebutkan bahwa penghasilan orang tua tidak berpengaruh terhadap literasi keuangan mahasiswa. Penghasilan orang tua yang tinggi bukan merupakan ukuran tingginya tingkat literasi keuangan mahasiswa. Peran orang tua dalam memberikan edukasi mengenai keuangan akan sangat mempengaruhi anak dalam mengelola keuangannya.

\section{KESIMPULAN DAN SARAN}

\section{Kesimpulan}

Berdasarkan hasil penelitian dapat disimpulkan bahwa: 1) Tingkat literasi keuangan mahasiswa Universitas Darma Persada termasuk kategori baik. 2) Penghasilan mendorong literasi keuangan mahasiswaFakultas Ekonomi Universitas Darma Persada, sedangkan usia, jenis kelamin dan pendidikan tidak mendorong peningkatan literasi keuangan.

\section{Saran}

1. Memperluas wilayah penelitian agar hasilnya dapat digeneralisasikan.

2. Menggunakan bentuk metode penelitian yang lain, seperti literasi keuangan dijadikan variabel moderasi atau menjadikan sebagai variabel intervening. 
3. Menambahkan variabel lain yang dapat mempengaruhi ke dalam variabel literasi keuangan, seperti pengalaman kerja, academic ability.

\section{DAFTAR PUSTAKA}

Angela C. Lyons \& Josephine Kass-Hanna (2019). Financial Inclusion, Financial Literacy and Economically Vulnerable Populations in the Middle East and North Africa. DOI: 10.1080/1540496X.2019.1598370

Huston, Sandra J. 2010. Measuring Financial Literacy. The Journal of Consumer Affairs Vol 44 No 2.

Herawati, Nyoman Trisna.2017. Seminar Nasional Riset Inovatif. Hal 131-137

Laily, Nujmatul. 2013. Pengaruh Literasi Keuangan terhadap perilaku mahasiswa dalam mengelola keuangan. Journal of Accounting and Business Education.

DOI: http://dx.doi.org/10.26675/jabe.v1i4.604

Yusnita, Raja Ria dan Abdi, Muhammad. (2018). Pengaruh faktor Demografi terhadap literasi keuangan. Journal of Economic, Business and Accounting. Vol 2 No 1 JuliDesember 2018. Hal 163 - 184

OJK. 2017. Survei Nasional Literasi dan Inklusi Keuangan (SNLIK). (online) diakses di http://www.ojk.go.id/id/berita-dan-kegiatan/siaran-pers/Pages/Siaran-Pers-OJKIndeks-Literasidan-Inklusi-Keuangan-Meningkat.

Oksana Kabakova dan Evgeny Plaksenkov. 2018. Analysis of factors affecting financial inclusion: Ecosystem view. Journal of Business Research (2018).

https://doi.org/10.1016/j.jbusres.2018.01.066

Olubanjo Michael Adetunji dan Olayinka David-West. 2019. The Relative Impact of Income and Financial Literacy on Financial Inclusion in Nigeria. Journal of International Development. Published online in Wiley Online Library (wileyonlinelibrary.com). https://doi.org/10.1002/jid.3407

Peter J. Morgana dan Trinh Quang (2020). Financial literacy, financial inclusion, and savings behavior. Journal of Asian Economics Vol 68. https://doi.org/10.1016/j.asieco.2020.101197.

Prayogi, Febrianto Dwi dan Haryono, Nadia Asandimitra. (2017). Literasi Keuangan pada Masyarakat Bangkalan Madura. Seminar Nasional Riset Inovatif. Hal 579-586

Sirine, Hani dan Utami, Dwi Setiyani. 2016. Faktor-faktor yang mempengaruhi perilaku menabung di kalangan Mahasiswa. Jurnal Ekonomi dan Bisnis Vol 19 No 1 April 2016. Hal 27-52

Sugiyono. 2018. Metodologi Penelitian Kuantitatif, Kualitatif dan R\&D. Bandung: Alfabeta

Wati, Lela Nurlaela. 2018. Metodologi Penelitian Terapan Aplikasi SPSS, Eviews, Smart PLS dan Amos. Edisi Revisi, Bekasi: CV Pustaka Amri 